Research article

\title{
A self- governing reserve army of labour? The commodification of the young unemployed through welfare policy, practice and discourse
}

\author{
Lou ise Prendergast* \\ Bangor University
}

\begin{abstract}
This article explores the experiences and discourses of precarious work and welfare from the perspectives of young people who are unemployed or in precarious employment, and frontline staff broadly involved in welfare practices. The narratives of unemployed young people and frontline workers, within an area of Wales, offer a snapshot of work and welfare from 2015; with young people a 'litmus paper' of the landscape and frontline workers as street-level bureaucrats (Lipsky, 2010). The main findings discussed here are that any work and work schemes are regarded as an appropriate solution for the 'problem' of unemployment by both young people and frontline workers, who valorise work and denigrate welfare. Young people compete for, and frontline workers encourage, unpaid and paid labour market participation, whether stable employment is forthcoming or not, and focus on individualising effort and hard work. This is not new, discipline by welfare stigma and the elevation of work has guided workers both now and historically, and a deliberate commodification of labour with work schemes and 'work first' approaches, alongside welfare sanctions ensure individuals labour for profit (Daguerre and Etherington, 2014; Grover, 2012). Drawing on the concepts of 'governmentality' (Foucault, 1994a) this article argues that the problematizing of the unemployed, and centrality of work and the work ethic, has contributed to young people, particularly those without financial resources, to become a resilient self-governing and effortful reserve army of labour, shaped through discursive practices.
\end{abstract}

Keywords: work, welfare, policy, unemployed, governmentality.

\section{Introduction}

Since the late 1970s, there have been significant changes in the UK labour market and welfare policy. Employment is less 'typical' and precarious forms of employment are increasingly the norm; defined by job insecurity and low pay as well as a lack of collective bargaining or union representation (Clarke and Cominetti, 2019). Working 
p. 263. A self- governing reserve army of labour? The commodification of the young unemployed through welfare policy, practice and discourse

practices with non-guaranteed zero-hour contracts doubled between 2007 and 2013 (ONS, 2014), and whereby in 2006, 18.1 per cent of workers were in precarious employment, in 2016, this had increased by 22.2 per cent to 2 million people, over one in five workers (Booth, 2016). Employment insecurity and low pay have been a persistent labour market trend for the young and unqualified (Bell and Blanchflower, 2013; Keohaneand Hupkau, 2014), with 58 per cent of aged 16 - 20 in low paid work in 1990, rising to 77 percent in 2015; for those aged 21 to 25 this rose from 22 per cent to 40 per cent (Clarke and D'Arcy, 2016). Many employment opportunities are predominantly in retail, accommodation, food, care services and leisure industries, which all feature low union activity, and rather than a step into better-paid and se cure employment, represent stagnation (Hurrell, 2013; Whittaker and Hurrell, 2013, Keohane and Hupkau, 2014). Nonetheless, unemployment rates have fallen, at 3.8 per cent in 2019, from eight per cent in 2008 (ONS, 2019). With a flexible labour market and limited collective bargaining, employers are in a better position to hire and fire and face little pressure to pay higher wages, and as Bell and Gardiner (2019) suggest, these figures may indicate that people are working more to com pensate for smaller earnings and lower income received elsewhere.

Welfare policy has seen considerable changes parallel to a shifting economy. Young people, targeted with tighter eligibility and reduced benefits, have been conceptualised as lacking in experienceand skills at a time when they were, in fact, more employable, enjoying higher levels of education and formal qualifications in comparison to the late 1970s (Crisp and Powell, 2016). Nonetheless, the 2010-15 Conservative-led, liberal democrat coalition government's welfare policies were driven by concerns of a deficient workforce and a burgeoning welfare dependency, culminating in aims to encourage personal responsibility and 'activate' all unemployed (Wiggan, 2012). The centrality of work underpinned their discourses and policies, with the assumption that any work could be a stepping-stone towards better work and pay, but it was for the individual to decide whether they wanted to progress. This was a sentiment summed up by unemployment minister, Esther McVey, who bluntly stated, 'You could be working in Costa. But in a couple of years' time, you might say, "l'd like to manage the area" or might even want to run a hotel in Dubai” (Perry, 2014). The government's Welfare Reform Act in 2012 solidified an already existing paradigm of activation and conditionality, strengthening the use of sanctions (the removal of benefits for nonparticipation) and reducing the availability of benefits. Alongside discourses of 'hardworking people' and 'non-working scroungers', their 'work first' approach mandated getting people into work as soon as possible, presuming that any employment was desirable, despite contrary evidence of individuals compelled to take low paid and precarious work under the threat of sanctions (Slater, 2012; Patrick, 2012; Briken and Taylor, 2018).

\section{Historical concerns and continuities}

Governments dictate how the unemployed are defined and subsequently managed within social policy, their responses are historically contingent as their political ambitions change. For example, during the post-second world war in the UK, there was a commitment to full employment and the development of the welfarestate protected citizens from periods of low labour demand; a 'safety net' providing mental and physical improvements to the workforce, enabling them to be more productive (Lowe, 1993, Renwick, 2018). In addition to well organised collective bargaining through unions, labour was somewhat de-commodified, and poverty associated with unemployment was alleviated (Greer, 2015). Throughout this post war period, the economy was generally robust with many employment opportunities. Economic 
p. 264. A self- governing reserve army of labour? The commodification of the young unemployed through welfare policy, practice and discourse

independence was achievable for young people through 'entry-level' work and paid apprenticeships although these were often overly tedious and repetitive (Campbell, 1984; Ainley, 2016). A period of change occurred following the economic crisis of the late 1970s, and alongside changing industries, there was a dearth of entry-level jo bs which left many unemployed, includingyoung people leavingschool. To add ress what was assumed to be a temporary issue, believing labour demand would increase, the Labour government in 1978 implemented the Youth Opportunities Program me (YOP), whereby young people were guaranteed a place on a training scheme, or work experience (Mizen, 2004; MacDonald, 2011). Significantly, labour demand did not resume, and many left schemes unemployed (Roberts, 2013).

As unemployment continued to climb in the early 1980s, following the global recession and government efforts to combat inflation, work schemes became embedded within policy, accompanied by the problematisation of young people as lacking a work ethic and requiring interventions to make them ready for the world of work (Mizen, 2004; MacDonald, 2011). This identified young people as deficient in finding and sustaining employment, and crucially obfuscated the mass structural unemployment at that time, as recounted by Davies (1986: 54), "Mass youth unemployment, it seems, resulted only from accumulation across the country of all these personal defects, individual by individual." Nevertheless, work schemes did enable employers to draw upon young people as cheap, state-funded disposable labour (Grover and Piggott, 2013). The Youth Training Scheme (YTS) introduced in 1983, gave employers full-time workers with no guarantee of a job, a realisation that was bluntly illustrated by the chair of the Manpower Services Commission, David Young, who presented the benefits of YTS to employers: 'You employers now have the opportunity to take on young men and women, train them and let them work for you almost entirely at our expense, and then decide whether or not to employ them.' (Davies, 1986:59).

Work schemes did face criticism for inculcating social discipline and selfimprovement, rather than providing vocational apprenticeships and training (Cohen, 1984), which was reflected by the thousands of schoolchildren who marched against a future of mandatory cheap labour with no guarantee of a job (Jeffries, 2016). Nonetheless, the YTS was made compulsory in 1988, followed by further schem es under the Conservatives including 'Project Work', a 'workfare' programme to tackle long term unemployment by mandating three month's work on a community project, with the proviso of moving people from the dole with dignity (Bevins, 1996). Concurrent with these developments, new right interest groups lobbied the government to weak en benefit entitlements, and promoted proposals on work and welfare, leading to the Social Security Act of 1985. This included designated approved trainingschemes, with benefits reduced for those who refused, and by 1988, participation in a youth training scheme was 'virtually compulsory' (King, 1995: 171).

The Restart programme in 1987 involved supply-side interventions to reduce unemployment, signified a shift from the labour transparency model of the early 1970 s, to one of benefit control. The programme was to help 're-motivate' the unemployed by offering a menu of options, including a restart course. It focussed on policing the unemployed, as frontlinestaff, Employment Service officials, would monitor their activity - an action subsequently criticised by the shadow Labour govern ment, as reminiscent of the 1921 genuinely seeking work test (King, 1995; Price, 2000). The following Social Security Act (1989) also required unemployed people to actively seek work and removed the right of the claimant to refuse jobs believing that job refusal would stand in the way of a flexible labour market (Price, 2000).

Up until 1996, there were relatively few requirements for accessing out of work benefits, however, in 1997 the Labour Government borrowed from the ideas of 
p. 265. A self- governing reserve army of labour? The commodification of the young unemployed through welfare policy, practice and discourse

Lawrence Mead, a US politics professor. Primarily, this was the understanding that work was the best form of welfare, and that individuals lacked social skillsto sustain a job; a problem of the unemployed which called for solutions of 'paternal istic welfare' (Field, 1998: 60-61). Labour moved further to embrace a wider population into work schemes and conditionality to access out of work benefits, including those who were previously peripheral to the labour market: lone mothers, the disabled and long-term unemployed (McQuaidand Lindsay, 2005; Sage, 2012). To deal with the problem of the unemployed and their perceived lack of employability, the 'New Deal' and 'New Deal for Young People' programmes were introduced to promote work orientation, funded initially by windfall taxes on profits of privatised utility companies (Trickey and Walker, 2001; Daguerre and Etherington, 2014). These schemes were firmly underpinned by discourses of individual motivation, and any barriers to employment were perceived as individual failures (Crisp, 2008). Welfare policieswere promoted as benevolent rather than prohibitory and assumed to provide a more personalised service underpinned by a paternalistic approach, to guide the individual to work (Grover, 2012; Trickey and Walker, 2001).

With the unemployed now regarded as clients requiring a 'personalised service', they were in effect commodified, and the market regarded as the most efficient providers in curtailing them away from the "socially regressive culture of dependency" (Purnell, 2008). The Conservative-led coalition government in 2010 introduced a wealth schemes for those unem ployed, with 'work for benefit' policies delivered by nonstate organisations, Third Sector and the private sector, competing to deliver these services (McQuaid and Lindsay, 2005; Egdell et al., 2016). Amongst these were the Work Programme, Mandatory Work Activity, and Work Experience programmes that consolidated the focus on the individual to improve their opportunities to find work and instil work disciplines (DWP, 2011; Wiggan, 2015). Young people especially were perceived by the government as not understanding the world of work, as they baldly stated, 'The work experience programme helps young people gain the experience they need to get a job. Some young people have difficulty finding a job because they do not fully understand the world of work or have not had a chance to prove themselves.' (Gov.uk, 2015). These schemes established to tackle worklessness and prevent benefit dependency, were also underpinned by discourses of work as unproblematically good, even valorised beyond remuneration (Patrick, 2012). Yet, increased sanctions and benefits conditionality were put steadfastly in place, to encourage work and work scheme participation (Deeming, 2014; Standing, 2014; Sage, 2019).

\section{Governmentality and the Reserve Army of Labour}

The understanding that government defines a population to manage it, aligns with the concept of governmentality associated with Foucault (1991). Foucault described governmentality as a type of power, whereby forms of knowledge are dispersed through 'agencies' and authorities to shape the conduct of individuals for specific, albeit (historically) shifting, governments' aims. Subsequently, there will be different rationales and knowledges that underpin the techniques which are used to govern populations (Dean, 2013). Of relevance here is the identifying and re-presenting the unemployed as a problem and framing them within a common, formalised language which makes them amenable to intervention (Miller and Rose, 2011). However, it is not only the production of knowledge of a population that is relevant, but its normalisation of this knowledgethrough discourseand practice. Individuals can govern them selves, carrying and constituting the effects of discourse, according to government aims through 'techniques of the self' (Fraser and Gordon, 1994). 
p. 266. A self- governing reserve army of labour? The commodification of the young unemployed through welfare policy, practice and discourse

Fairclough (2000) referred to governments' aims as being to produce 'docile bodies' who would meetthe needs of the economy. Put simply, the governm ent need an enthusiastic and willing workforce, a pool of labour, who could meet the demands of economic production - such as precarious, and low paid employment. Marx referred to a reserve army of labour for those who have irregular employment but are req uired to work in many jobs to sustain even a minimal amount of income. These were essential to capitalism, an ever-present supply of disposable labour that could furnish capital and sustain downward pressure on wages (Marx [1865] 2013:58). The reserve army is regulated by the state, maintained as sizable and kept close to the labour market, poised to serve and compete for employment (Grover and Piggott, 2005). Policies, including work schemes, sanctions and conditionality, can be considered practicesthat contribute to maintaining the jobseeker's closeness to labour (Grover, 2003). These offer a low wage and labour supply for the increasingly precarious and low paid work available (Mizen, 2004; Muncie, 2008) and for employers, a reserve army constituting a 'disposable commodity availableat a discount' (Dean, 2012:358).

\section{Methods}

This research drew on interviews from a purposive sample of young unemployed people and frontline welfare workers in areas of north and mid wales, in 2015. The aim was to recruit unemployed people aged $18-24$, an age group used to define young people in welfare policy (Trickey and Walker, 2001), however, the final sam ple included one 17, and one 30-year-old. Nine young unemployed people who had experienced financial and un/employment insecurity, and seven frontline workers were interviewed, included employment advisors on the Work Programme, and employment mentors on Welsh Government or Lottery funded initiatives. Following ethical consent obtained from Bangor University, narrative interviews were conducted to explore their perceptions and lived experiences of work and welfare, and to yield insight into their everyday knowledges (Wengraf, 2001).

Governmentality supposes that government extends beyond politics and is found in all facets of life (Foucault, 1994c; Miller and Rose, 2011; Dean, 2013); power is dispersed and can function in banal and uneventful ways, the 'common sense' understandings, norms and assumptions (Chamberlayne et al., 2000). Qualitative methods are particularly useful in exploring ideas and concepts individuals give to phenomenaand can help to understand how and where political thought exists, and how it is (re)produced through the (micro practices of) everyday life (MacDonald and Marston, 2005). Accordingly, qualitative narrative interviews were conducted to enable individuals to reflect on their personal experiences, with the understanding that the ir narratives too, convey discoursesas effects of governmentality.

All but one interview was conducted face to face, with most lasting for over an hour. These were transcribed and thematically analysed following Braun and Clarke (2006), and subsequently key themes were identified, discussed in this paper. It is worth noting here that this was a relativelysmall sample of participants, and therefore the findings from this research cannot be generalizable to a wider population of all young people. Nonetheless, these findings do offer some important insights of perspectives and experiences of work and welfare, as discussed in the following section. In reproducing the narratives, the names of participants have been changed. 
p. 267. A self- governing reserve army of labour? The commodification of the young unemployed through welfare policy, practice and discourse

\section{Work Schemes}

To recall, work schemes have been a consistent part of UK welfare policy since the 1970 s, therefore it is unsurprising that the young people interviewed were familiar with these. Pointedly, they spoke of these using terms that could be associated with paid work and competitive recruitment processes; being successful if selected and being 'let go from' when finished. Consequently, I had to probe to find out whether they were referring to paid employment or an unpaid work scheme. One participant, Sam, told me of his experiences of 'going for jobs' (work schemes) and relayed how he had been one of the few people selected following his interview. As well as the achievement of securing his placement, he went on to say that he was 'lucky' that this placem ent had been extended, attributing his success to being a 'hard worker'. Another participant, John, reflected you needed to gain an opportunity to prove your worth to the e $\mathrm{m}$ ployer and recounted how the Jobcentre having faith in his capabilities as a worker, ensured that he would always have work scheme opportunities,

"They are a good idea cos most people get jobs afterwards from the same company...it's just a case of finding someone that'll take you [... ]. I've had 2 interviews, which was for [shop]. (Jobcentre) try and put me into another one because they want me to go into another one cos they know l'll do it and they know l'll stay and things like that but it's just a case of work placements just not taking me." (John)

Sam too believed work schemes were a good idea in providing a potential opportunity to gain subsequent employment, having received promise so employment following the scheme, and believed that payment should comefrom the Jobcentre in addition to benefits, and not from an employer:

"Yeah, they said if you do the work very well you have a fairchance of getting a job afterwards [...]. What they should do if you are signing on, you should do is 10 hours a week, and that is 63 pounds which is a bit more than signing on, and if you done that, that's your basic, and you done more hours, then the Jobcentre pay you the difference the hours that you worked." (Sam)

Frontline workers reflected on work schemes as providing a 'definite possibility' of a job, that is, having the potential to lead to paid employment. Additionally, schemes were considered valuable in teaching work like behaviours and helping to make the young person more confident:

"Gives somebody work experience even if it only lasts 6 months, it gives them so much self-worth and confidence, it's an invaluable scheme, it really is, it really does help a lot of people [...] with a definite possibility of having a full time job after 6 months." (Ben, employment mentor)

"I mean it makes them think of work, that you get up, get up and prepare for work like I said I think the work experience is one of the best tools." (Bea, employment advisor)

Work schemes were sought after by front-line workers who were keen to get employers 'on board' to provide placements. Employers were described as 'really good' for taking on their clients and as one frontline worker noted, sometimes even retained young people after the placement. Three frontline workers recalled the role of the employment liaison officer, based within their company, who tracked em ployers and 
p. 268. A self- governing reserve army of labour? The commodification of the young unemployed through welfare policy, practice and discourse

thus gave their organisation an advantage over others, including the Jobcentre, as described by one employment adviser:

"We have got an employment liaison officer upstairs, and he goes around companies locally and he would ask if they've got any vacancies, and he would bring the vacancies back here and they would be specifically for our customers so sometimes, the Jobcentre don't even get to know about them, it's just for our comp... our ...you know...client base here, so that's one bonus that we've got really." (Anne, employment advisor).

Both young people and frontline workers referred to the same companies; shops and factories that offered placements; a continual engagement with familiar companies, a practice which may be instrumental into maintaining Work Program me targets (Ingold and Stuart, 2015).

\section{Mou lding the individual}

A criticism levied towards YTS work schemes in the mid-1980s was that they were a substitute for a paid job; the employer using the worker for free labour rather than employing them. Similarly, in 2017, the retailer the 'Poundland' was criticised for utilising free labour rather than providing work experience (Butler and Halliday, 2017). Rather than providing em ployers with free labour, frontline workers conceived of work, even if unpaid, as being transformative, and it was understood that this common sense needed to be conveyed to some young people. Frontline workers perceived that any client who refused to a participate in temporary employment, or a work scheme, was 'difficult to mould'. These were the clients that did not understand the fulfilm ent that work would bring, and such a concern was articulated through the figure of some one who had not experienced the pleasures of working, or 'winning', as relayed by one employment advisor:

"Less heating, they're not watching the telly all day, they are out meeting people, they're doing something and there's always the offer of overtime somewhere, so there are benefits of it somewhere, they may not become obvious but there are benefits, of actually doing the work for the same money....possibly [...]. They shouldn't be worse off, they may well be exactly the same .....and to me that's not worse off, because if you're gonna be the same, you're not losing out but you are gaining more in your personal skills....so you're winning, but you're not gaining, ok money." (Anne, employment advisor)

The benefits of work, even without pay, outweighed the perceived deprivation of unemployment, and those young people who did not appreciate working we re viewed as possessing a bad attitude or poor mental approach, a finding similar to Jordan's ethnographic research of the Work Programme (2018). Those who did not adopt a willingness to work needed to be challenged, as highlighted by two frontline workers:

“Their perception of work I think a lot of them are negative, they just don't seem to, not interested somehow, lack motivation." (Bea, employment advisor)

“We arrange work tasters if you like, there's always a handful who don't turn up on the day. They speak the speak, you know, they want to do it when it comes to the day they don't go. A lot of them can't be bothered, or they've changed their mind, or they've decided or spoken to someone oh I wouldn't do it for 2 weeks 
p. 269. A self- governing reserve army of labour? The commodification of the young unemployed through welfare policy, practice and discourse

with no money oh l'm not doing it either...so, yeah there's a lot of talk. [...] These are the ones not willing to do the work trials, you know, why should I do it for nothing... they are a difficult group... they are a difficult group, because you can't mould them." (Anne, employment advisor)

\section{The good worker, the effortful citizen}

A major shift towards greater conditionality, that is, demonstrating work search activities, to receive out of work benefits occurred with the introduction of Jo bseekers Allowance in 1996, (Fletcher and Wright, 2018). More recently, the Welfare Reform Act (2012) increased the conditionality to receive benefits to reduce 'habits of worklessness' (Deeming, 2014). Moreover, these more stringentreforms have been significant in demonstrating to the public that the benefit recipient has maintained their 'obligations' to find work to the 'tax payer', a sentiment captured by lain Duncan Smith, then secretary of state for work and pensions, 'Those in work have obligations to their employer; so too claimants a responsibility to the tax payer: in return for sup port, and where they are able, they must do their bit to find work.' (Gov.uk, 2014).

Despite the role of conditionality to mandate people to work search, a key finding was that young people readily engaged in job searching because they believed their activities demonstrated their work ethicand effort to potential employers. They referred to constant job applications, doing the 'CV drop' (taking the CV to potential employers), and undertaking voluntary work, proving their employability and willingness to work, even without a wage, as both John and Holly explained:

"Volunteering is sort of higher than work itself, cos you know you are using your time and you're not getting benefits for it; it's all cos you want to do it [...]. People when they work, they're just doing it mainly for the money cos they just sort of have to but when yourvolunteeringyou're putting yourself out there so, yeah, it's better." (Holly)

"Every shop in [...] had got one of my CVs (is that something that you are advised to do...?) No, I do that off my own back, it's showing that lam willing to work and will do anything to get work I'm taking my CV in but I'm just not getting anything back."(John)

Yet, despite striving to appeal to employers, when young people did not hear back from employers, they spoke of experiencing feelings of failure and disillusionment, a nd three referred to being on medication because of anxiety and depression.

Within a competitive jobs market, the onus is on the individual to apply for jobs, but not for the employer to respond. Shidrick et al. (2012) presented similar stories of individuals feeling worn as they expended emotional and physical efforts in job seeking, and as Standing (2014) reflects, feeling unrewarded for 'work for labour' accompanied by apparent failure can be internalised, leading to listlessness. Such rejection and disillusionment of young people was echoed by frontline workers - not only when there was no response to job applications, but also from work schemes, as one employment mentor stated:

"So, I've had clients go there and be rejected on the work trial to do the work trial. If they pass the work trial to do a work trial, they're employed for a month without anything, without pay, I've seen it a few times [...] young person then, becomes 
p. 270. A self- governing reserve army of labour? The commodification of the young unemployed through welfare policy, practice and discourse

very disillusioned, becomes, er, very er, self-critical if you like." (Ben, Employment mentor)

Nonetheless, frontline workers encouraged young people to be self-reflexive, to see what they could do differently to 'sell themselves' to employers. This included undertaking the practical steps to ensure that they met their conditions as part of the ir Job Seeker Agreement, such a maintaining the paper trail of jobs applied for. It also included more personal support, such as maintaining the young person's effort and motivation, to keepapplying for jobs, highlighted by frontline workers:

"It's a learning curve, you build up on that time and time again, even though it can be quite soul destroying, we all know that we've all had interviews where we've been turned down, it is a confidence boost thing I think, you build that up all the time." (Anne, employment advisor)

"You know the deadline's gone and they've not been called for an interview, they've reapplied for the job and they've not been called for interview, and we might sit there and we might tweak their CV and say 'well what is it that needs to change on your CV, to make you more desirable to the employer?' And that's still very, very, frustrating foryoung people. [...]. They'vegot to have a papertrail as it were, or a digital trail to show that they've sent those emails um, so again working with young people to get them skilled up to understand that process whilst they are unemployed, they need to develop skills with us to sustain the low level income they are currently on really." (Dave, employment mentor)

\section{The threat of sanctions}

As well as welfare conditionality, sanctions are a part of welfare policy that serve as a backstop to ensure that claimants adopt 'values' of work. Sanctions have increase d in severity and regularity since the 2012 Welfare Reform Act and continued, despite the Parliament's own Work and Pension's Select Committee findings of an ineffective ness to help people into work (Parliament.uk, 2017; Whitworth and Carter, 2014). With a sharp increase in benefit sanctions for young people under 25 claiming Job Seekers Allowance (Watts, et al., 2014; Webster, 2014) it was no surprise that young people were aware of benefit sanctions, and three had experienced them:

"I was always very careful to make sure I was on time ...but it does add another degree of stress, to the whole experience if you know that you are 10 minutes late you're gonna get sanctioned." (Rhys)

The young people who saw that they had followed the rules referred to sanctions as a punishment, and they were wrongfully convicted. Moreover, they felt that they could not defend themselves against the arbitrary decisions, even when they had exhibited the correct behaviour:

“When I went to sign on I told them it weren't me, I hadn't applied or anything but they didn't check it up, or chase it, they sanctioned me for it cos they tho ug ht I'd got other payments and that, and then 4 weeks later they phoned me up and was like said that they were sanctioning me, then took me off sanctions and didn't pay me back." (John) 
p. 271. A self- governing reserve army of labour? The commodification of the young unemployed through welfare policy, practice and discourse

“It's like a punishment isn't it...it's like a punishment [pause] for quitting your job...they say you know we're going to stop your benefits [...] I was mortified and obviously l'd lost all my benefits after that as well, so I had no money to live off for a long time. I wasn't given an opportunity to really defend myself. Copies of the things that my employers said about me, and basically, it didn't match up with the things I said, and that I was going to lose all my benefits.... writing out forms, filling forms, writing state of events, and everything else - not one-on-one meetings." (Judy)

Sanctions work discursively as an omnipresent threat and push the risks of not finding or sustaining work onto the individual who must take personal responsibility in demonstrating the 'correct' behaviour to access benefits, without wage demands or job expectations (Wiggan, 2012; Standing, 2014). The terms used within policy, 'breaches' and 'offences' infer choice, fairness, and criminal conduct, put simply, the individual risks punishment if they govern themselves wrongly (Fletcher and Wright, 2018). Accordingly, frontline workers perceived sanctions as fair for those who broke contractual arrangements, for example, when the young person did not keep their work search diary or did not turn up to sign on or keep their work programme appointme nt. Nonetheless, they recognised some were undeserving of sanctions having exhibited the correct job seeking behaviours but had been subject to administrative errors or were not fit for work. These were dealt with through discretion, as one employment a d visor described her 'street level bureaucracy' (Lipsky, 2010) managing clients not fit for work:

“They come and they're on jobseekers they're not fit are they, who'd employ you...so I might just say, (whispers) 'why don't you go and see your doctor and see what they say', and if they don't I might just say, 'right then, shall we just say, shall we just say, can you just drop your CV somewhere then', because I don't think they are going to get a job, but there again, I don't want more pressure they're on jobs (Jobseekers Allowance)." (Bea, employment advisor)

\section{Stigma: the deserving and the undeserving}

Stigma can be defined as what marks an individual as deviant from an established societal norm, as Goffman observed, this was 'The standards he has incorporated from wider society equip him to be intimately alive to what others see as his failing, inevitably causing him, if only for moments, to agree with what he does indeed fall short of what he really ought to be' (Goffman, 1990: 15). Previous research has highlighted the discourses within policy and media that have marked out those in receipt of benefits as shameful (Tyler, 2013; Baumberg, 2016). Young people were acutely aware of the spectre of benefits stigma and being viewed by others as not effortful enough. They referred to themselves as hard workers and wished to avoid the ubiquitous scrounger label; no one wanted to sign on, and no one regarded out of work benefits as an inalienable right. Rather, they felt judged according to the norms of work as a contribution to society, and their own attachment to work and work ethic, as illustrated in the quotes below:

"Forme, cos l've always worked, the whole... unemployed thing and feeling like I wasn't contributing to society and all this, and people were judging me and all this, I found it difficult, really difficult, and even though I was doing everything I could, it seemed to be getting harder." (Rhys) 
p. 272. A self- governing reserve army of labour? The commodification of the young unemployed through welfare policy, practice and discourse

"I'm finding it really daunting now being out of employment, and l'm also feeling the need to tell everyone you know that I, I was employed for such a long time. You know what I mean? Because everyone just looks at you differently. It's really difficult to explain, but I think they judge you as someone that's lazy, as someone who doesn't really want workyou know." (Judy).

This fear of a negative judgement for not working and claiming benefits is not uncommon (Shildrick et al., 2012; Frayne, 2015). Front-line staff judged young pe o ple according to their own evaluations (Lipsky, 2010), categorising them according to common sense types. Some were 'undeserving' of benefits, giving other claimants a bad name. These were a type that everyone knew; probably from a housing estate, a well-used derogatory label inhabited by certain 'types' of people, and a symbolic place within public, media and political discourse (see McKenzie, 2015; Crossley, 2017). The ideal welfare subject was someone who felt stigma and shame in claiming benefits, akin to the pervasive anti-welfare common sense culturally perpetrated via "poverty porn', as described elsewhere (Jensen, 2014; Jensen and Tyler, 2015). Moreover, frontline workers commented that young people needed to disasso ciate the mselves from these 'types':

“I've got clients that judge scroungers themselves, say - 'I'm desperate to work, yeah, I want a job, I get pissed off with people' he says 'that are sat on their arses all day, people that are on sick and there's fuck all wrong with them, and I wanna to work'. I hear that quite a lot from clients... and so even unemployed people can be resentful of unemployed people cos they give them a bad name." (Ben, employment mentor)

Others were 'deserving', natural 'grafters' who had role models, could get up ea rly, and demonstrated their work ethic, and importantly experienced shameand stigma in signing on as one frontline worker recollected:

"And then you look at Paula, in the flats, and she feeds her kids on pizza and micro oven chips, and you ask a sociologist why she's like that and they'd say poverty but what makes them different it's just interesting, Johnny is a grafter and he hates being out of work." (Matt, employment mentor)

Patrick (2016) reflected that claimants described an absence of respect and a sense of dehumanisation, when they encountered Job Centre and Work Programme staff. However, the perception that some people should not have any rights to welfare was also a conclusion drawn by some young people interviewed. Holly, in receipt of Income Support, proposed that more out of work conditionality was the obvious solution to the problem of the undeserving:

"People now on benefits.... and people don't do anything, which is their fault sometimes, I guess they are changing things, you could stay at home and do nothing um so yeah, they do need, that's why I like the Universal Credit cos it forces you to go out and help so that's good [...]. I know some people do sort of lie about it they don't necessarily need it, they'll use that money fordrugs, alco hol, whatever so that's why they're changing it getting more serious and stern about it which is important cos in a way they're spending millions and giving it away to the wrong people but I think they haven't thought about everything properly, fully enough." (Holly) 
p. 273. A self- governing reserve army of labour? The commodification of the young unemployed through welfare policy, practice and discourse

The themes shared by young people and frontline workers - the importance of work, and the stigma of welfare, appearing as common-sense concerns are relevant in informing interventionist welfare policies. Undoubtedly conceived as individualised issues, these concerns contribute to governing and help to elide any discussion of structural issues of pay, work availability and conditions. This concern is developed in the final section, with reference to governmentality.

\section{A self-regulating reserve army of labour, governmentality and the conduct of conduct}

Shifts and continuities in the aims of government are underpinned by different rationales which lead to various policies and practices to govern the unemployed (Dean, 2013). Most recently, individuals who are unemployed and require state benefits for financial support have been problematizing as workshy and requiring interventions (Miller and Rose, 2011). Young unemployed people have been labelled as 'deficient', subsequently needing to learn work-based behaviours and a work ethic, and as such, welfare policies have cemented the focus on the individual. From the New Labour government, an industry of 'quasi-autonomous agencies' have been responsible for managing those the unemployed, with regimes of practices, such as work schemes, to 'guide' people into work. These have focussed on the individual and aimed to reproduce in them desirable worker characteristics - the right worker attitude, hopeful and permanently poised to take any work. Furthermore, such schemes instigate competition for low paid insecure jobs, rather than supporting individuals into secure and well-paid employment (Wiggan, 2015). Placements on work schem es are made inherently compelling as they are sought after by frontline workers and competed for by young people. This apparent reward of being chosen as a regime of practice, is a form of productive power, and serves to deflect from scrutinising social relations, as Marx wrote:

"The more he works, the more he competes against his fellow workmen, the more he compels them to competeagainst him, and to offer themselves on the same wretched conditions as he does; so that in the last analysis, he competes against himself as a member of the working class." (Marx 2013, 45 \{1847\}).

The competition, individualised effort and gratitude maintained through programmes and discourses contribute to the conduct of conduct, or governmentality, as young people maintain themselves as employable, selling themselves, whilst being told that they should be happy and committed having any job (Cruikshank, 1999, Foucault, 1994a; Standing, 2014). To be grateful for anyjob and remain positive was a concern raised in 1937, raised by Walter (Wal) Hanningon, in 1937, organiser of the National Unemployed Workers' Movement:

"If men are made to feel that they should be satisfied with a condition where they work for a labour exchange or U.A.B. [Unemployment Assistance Board] pittance, then the tendency will be to regard themselves as fortunate if they can get an ordinary job at wages fare below trade union standards." (Cited in Fletcher, 2015, 337).

Evidently, valorised work and denigrated welfare are normative ass umptions that have acquired a 'status of truth' articulated through policy and practice (Foucault, 1994b). Front-line workers adopt this (historically) dominant position of welfare dependency (Marston, 2013), and maintain their client's resilience and confidence, 
p. 274. A self- governing reserve army of labour? The commodification of the young unemployed through welfare policy, practice and discourse

'strengthening the capacity of the individual' (Millar and Rose 2008, 105). Through personalised, apparently benign interventions, they propagate discourses of (valorised) work and (denigrated) welfare, and are complicit in shaping the competitive, selfeffortful and enterprising individual, to work on themselves to be chosen for work, paid or unpaid (Grover, 2012; Whitworth and Carter, 2014).

The young person is always applying themselves to finding and sustaining work, for example, through voluntary participation in a work scheme, to make themselves available and attractive to employers, predominantly within the 'low skilled' labour market (Soss et al., 2011). To demonstrate their potentiality of employability, is a form of individualisation, "[it] implies a heightened and dangerous form of individual is $\mathrm{m}$. To achieve personal success or excellence 'every day' means to be permanently selfpossessed, to avoid communicating insecurities and self-doubts, to be always constantly and aggressively preoccupied with oneself' (Costea et al., 2012:34). It is the pressure to remain em ployable, that bestows a 'restless sense of endless potentiality' that is more powerful for individuals lacking in financial security (Frayne, 2015: 77). The policy, practice and discourses which maintain young people to be presentable, flexible, accessible, and eager for work, and work on themselves can lead to internalised failure to 'progress' (Brown, 2015).

The focus on the work ethic and effort from young people and frontline workers emphasises personal responsibility, and sanctions give the illusion of choice and autonomy, and in turn helps to construct 'docile bodies' that are to be complacent, subjected to, and improved through policy interventions (Weeks, 2011:53). However, the young person must internalise these dominant values and norms and hold themselves and others according to these. It is where attitudes and conduct are shaped, according to that which is expected and desired, that there signifies a 'biopower' of government (Foucault, 1980; Cruikshank, 1999; Dean, 2013). Young people market themselves as enterprising and effortful, 'self-policing' governed without coercion, and an attachment to the desirability to work (Frayne, 2015: 78). To quote Butler 'dependent on a discourse that was not chosen, but that paradoxically, initiates and sustains agency' (1997:2).

Stigmatization of the unemployed as a form of governance is not new (Tyler, 2013). New Labour's stigmatising rhetoric of deficient workless and welfare dependency underpinned their policies a 'culture of poverty' espoused by Frank Field (then minister for welfare reform) (Field, 1998). What may be considered here is that the work for labour and eagerness to take any job underpinned by a work ethic and stigma, is significant in the reproduction of labour power (Wiggan, 2015), as a self-exploiting and self-governing docile body has an increased economic use, to unquestionably serve employers, job creators (Foucault, 1991).

The policies and discourses underpinned by the individual's potential to labour, and contributing to a self-conditioning, resourceful and resilient individual, are so mething Dwyer and Ellison (2009: 65) presciently reflected on when reporting on New Labour's welfare to work regimes:

"There is a sense not just of conditionality, but of self-conditioning as perceptions about the necessity of work - and the individual's responsibility not only to find work but to have a life shaped by work - become embedded and ultimately 'assumed'. Overtime, assumptions are institutionalized and so become an integral part of a new consensus about work and welfare."

The trajectory of welfare conditionality, sanctions and work schemes help ensure that young people, without financial resources other than welfare benefits, a re willing 
p. 275. A self- governing reserve army of labour? The commodification of the young unemployed through welfare policy, practice and discourse

and available to serve low paid labour. As experience becomes normalised over pay, this extends the reserves of labour in close proximity to the labour marketwith "lowered expectations' (Umney, 2018: 63), and as a self-disciplining reserve army of labour, form an inexhaustible reservoir of disposable labour power for exploitation (Marx, 2013:58 \{1865\}).

\section{Conclusion}

This article has broadly traced the contingencies of government in dealing with and managing the unemployed from the late 1970s, with work schemes found to have been strengthened as a legitimate intervention, as evidenced by their subsequent reincarnations. Unemployment has been regardeda problem of the unemployed thus rendering individuals amenable for (supply side) interventions. This article has drawn on the narratives of young people and frontline workers to draw attention to their experiences and perspectives of work and welfare. Through a Foucauldian lens of governmentality, it has demonstrated the prevalence of discourses of welfare stigma and valorised work and aligned this to the current aims of government to maintain a self-governing and buoyant, reserve army of labour for insecure and low paid employment. Front line workers have been shown to carry discourses within practices that encourage their clients towards any job or work scheme, and to introspectively reflect on any labour market failures. In short, their practices encourage their 'client' to adopt the behaviours, attitudes, and skills that ensure that they are a commodity for 'purchase by capital' (Wiggan, 2015:372).

Governmentality assumes that power is productive, it is subtle and dispersed through discourse, policy and practice, and these findings raise some important implications for future welfare policy that maintain paternalistic and therapeutic interventions. If the individual is the problem, and work is the cure, this allows for medicalised discourses assessing attitudes and behavioural norms; psycho-policy interventions to guide the individual away from welfare and towards work (Friedli and Stern, 2014). Additionally, individualising discourses deflect from the scrutinising and critiquing of social relations, and legitimate punitive welfare policies and low paid precarious em ployment and thus contribute to unpaid labour becoming normative. If getting a job resides only with the individual's effort, this obfuscates unequal access to money, resources, barriers to skills and training. Universal Basic Income (UBI) (e.g. Standing, 2014) has been proposed, a basic income paid to all individuals, to untie 'behavioural' terms and conditions associated with welfare. However, there needs to be a 'counter-hegemonicstrategy' to unbind the current common-sense commodification of labour (Srnicek and Williams, 2015). Alongside challenging the narrative of benefits stigma (Baumberg, 2016; Patrick, 2016) there must be a scrutinising of the centrality of work and work ethic (Cole, 2007; Frayne, 2015). This is not to dispute that work paid or unpaid does provide positive functions, but that the knowledge that work is a I ways worthwhile within discourse, policy, and practice obscures the discussion of structural considerations, and may contribute to internalised self-blame for any labour market 'failure'.

Nonetheless, contradictions and contestations within the "dominant hegemonic ideologies' (articulations of Governmentality) can give scope to other ways of thinking, otherwise ruled out and restricted (Larner, 2000). Front-line workers spoke of some young people who did appear to refuse to engage in their welfare strategies of support, seen as 'difficult to mould' in not wanting to apply for low paid, insecure and temporary jobs, and not being 'receptive' to the help and advice offered. This could suggest that some young people are exercising their power in refusing to accept their 'needs' as 
p. 276. A self- governing reserve army of labour? The commodification of the young unemployed through welfare policy, practice and discourse

defined in policy and through practice, highlighting the disjuncture between political rationalities and the effects 'on the ground' (Cruikshank, 1999; Prior and Barnes, 2011). Peterie et al. (2019) recognises that acts of resistance must be considered and asks too, what the implications on the society and government might be, if the unemployed were collectively angry.

To conclude, where 'problems' of the unemployed continue to inform policy solutions, and the unemployed are shaped through discursive practices to become resilient labour, ongoing empirical research is required to investigate on the ground experiences, concurrent with the shifting UK socio-economic landscape and welfare reforms. This article has focussed on those in receipt of benefits, as well as frontline workers. However, as Crossley (2017) observes in his examination of spaces of poverty, the construction of policies and normalisation of discourses warrant investigation, that is, research is required that focusses on those that produce and arrange policy and discourse, whilst at the same time disavow the effects of their responsibility.

*Correspondence address: Louise Prendergast, Bangor University, l.prendergast@bangor.ac.uk

\section{References}

Adler, M. (2016) A New Leviathan: Benefit Sanctions in the Twenty-first Century. Journal of Law and Society. 43, 2, 125-227.

Ainley, P. (2016) Betraying a Generation How education is failing young people. Bristol, UK: Policy Press.

Baumberg, B. (2016)The Stigma of claiming benefits: a quantitative study. Jo urnal of Social Policy, 45, 2, 181-199.

Bell, D. and Blanchflower, D. (2013) Underemployment in the UK revisited. National Institute Economic Review. 224.

Bell, T. and Gardiner, L (2019) Feel poor, work more Explaining the UK's record employment. Resolution Foundation [online] Available at: https://www.resolutionfoundation.org/publications/feel-poor-work-more/ [Accessed: 20/01/20]

Bevins, A. (1996) Major unveils his lean welfare machine. The Independent [online] Available at: https://www.independent.co.uk/news/major-unveils-his-leanwelfare-machine-1357318.html [Accessed: 25/02/19]

Booth, R. (2016) Morethan $7 \mathrm{~m}$ Britons now in precarious employment. The Guardian. [online] Available at: https://www.theguardian.com/uknews/2016/nov/15/more-than-7 m-britons-in-precarious-employment [Accessed: 25/02/19]

Braun, V. and Clarke, V. (2006) Using thematic analysis in psychology. Qualitative Research in Psychology, 3, 2, 22-101.

Bricken, P. and Taylor, K. (2018) Fulfilling the 'British way': beyond constrained choice-Amazon workers' lived experiences of workfare. Industrial Relations Journal, 49, 5-6, 438-458.

Brown, W. (2015) Undoing the demos: Neoliberalism's stealth revolution. New York: Zone books.

Butler, J. (1997) The psychic life of power Stanford: Stanford University Press.

Butler, S. and Halliday, J. (2017) Poundland 'gets jobless to work for free under government scheme. The Guardian, [online] Available at: https://www.theguardian.com/business/2017/aug/30/poundland-work-freegovernment-scheme-dwp [Accessed: 21/01/19] 
p. 277. A self- governing reserve army of labour? The commodification of the young unemployed through welfare policy, practice and discourse

Campbell, B. (1984) Wigan pier revisited. London: Virago Press.

Chamberlayne, P, Bornat, J. and Wengraf, T. (2000) Introduction: The biographical turn. In: Chamberlayne, P. Bornat, J. and Wengraf.T. (eds) The Turn to Biographical Methods in Social Science. London: Routledge, 1-30.

Clarke, S. and Cominetti, N. (2019) Setting the Record Straight. How record employment has changed the UK Resolution Foundation Report [online] Available at: https://www.resolutionfoundation.org/app/uploads/2019/01/Setting-therecord-straight-full-employment-report.pdf [Accessed: 12/12/19]

Clarke, S. and D'Arcy (2016) Low Pay Britain 2016 [online] Available at: https://www.resolutionfoundation.org/publications/low-pay-britain-2016/ [Accessed: 10/12/19]

Cole, M. (2007) Re-thinking Unemployment: A Challenge to the legacy of Jaho da et al. Sociology, 41, 1133.

Cohen, P. (1984) Against the New Vocationalism. In: Bates, I., Clarke, J., Cohen, P., Finn, D., Moore, R. and Willis, P. (eds) Schooling for the Dole. London: Macmillan Publishers Ltd, 104-170.

Costea, B., Amiridis, K. and Crump, N. (2012) Graduate Employability and the Principle of Potentiality: An Aspect of the Ethics of HRM. Journal of Business Ethics, 111, 1. 25-36.

Crisp, R. (2008) Motivation, morals and justice: discourses of worklessness in the welfare reform green paper. People, Place and Policy Online, 2/3, 172-185 [online]. Available at: https://extra.shu.ac.uk/ppponline/issue_3_121108/documents/motivation_morals justice_worklessness_or eenpaper.pdf [Accessed: 26/04/19]

Crisp, R. and Powell, R. (2016) Young people and UK labour market policy: A critique of 'employability' as a tool for understandingyouth unem ployment. Urban studies, 124.

Crossley, S. (2017) In Their Place. The Imagined Geographies of Poverty. London: Pluto Press.

Cruikshank, B. (1999) The will to empower. New York, US: Cornell University Press.

Daguerre, A. and Etherington, D. (2014) Welfare Reform in the UK under the Conservative led Coalition government: ruptures and continuities. WorkingPaper ESRC June 30, 2014. Economic and Social Research Council, [online]. Available at:

http://workfare.org.uk/images/uploads/docs/Welfare Reform in the UK PubR eady.pdf [Accessed: 24/02/19]

Davies, B. (1986) Threatening Youth: Towards a National Youth Policy. Milton Keynes: Open University Press.

Dean, H. (2012)The Ethical Deficit of the United Kingdom's Proposed Universal Credit: Pimping the Precariat? The Political Quarterly, 83, 2.

Dean, M. (2013) Governmentality Power and Rule in modern society. London: SAGE publications.

Deeming, C. (2014) Foundations of the welfare state - reflections on the political transformation of the welfare state. Social Policy and Administration, 49, 7, 862886.

DWP (2011) The Work Programme [online]. Available at: https://assets.publishing.service.gov.uk/government/uploads/system/uploads/a ttachment data/file/49884/the-work-programme.pdf

Dwyer, P. and Ellison, N. (2009) Work and Welfare: the rights and Responsibilities of Unemployment in the UK. Chapter 3 2009, pp 53-66 in: The politics of unemployment in Europe: Policy responses and collective action Eds: Giugni, Marco. Surrey: Routledge.

Egdell, V., Dutton, M. and McQuaid, R. (2016) Third Sector Experiences of the Work Programme. Journal of Social Policy, 45, 4, 729-746. 
p. 278. A self- governing reserve army of labour? The commodification of the young unemployed through welfare policy, practice and discourse

Fairclough, N. (2000) Discourse and social change. Cambridge: Polity Press.

Field, F. (1998) Re-inventing Welfare: A response to Lawrence Mead. In: Mead, M. Lawrence (1998) From Welfare to Work: Lessons from America. London: The Health and Welfare Unit, Suffolk: St Edmundsbury Press.

Fletcher, D.R. (2015) Workfare - a blast from the past? Contemporary work conditionality for the unemployed in historical perspective. Social Policy and Society, 14, 3, 329-339.

Fletcher, D.R and Wright, S. (2018) A hand up or a slap down? Criminalising benefit claimants in Britain via strategies of surveillance, sanctions and deterrence. Critical Social Policy, 2, 323-344.

Foucault, M. (1980) Prison Talk. In: Gordon, C. (Eds) Power/Knowledge Selected Interviews and Other Writings 1972-1977. New York: Vintage Books, 37-54.

Foucault, M. (1991) Disciplineand Punishment. The Birth of Prison. Lond on: Penguin Books.

Foucault, M. (1994a) Governmentality. In: Faubion, J. D. (ed) Power, Essential works of Foucault 1954 - 1984. London: Penguin Books, 200-222.

Foucault, M. (1994b) Questions of method. In: Faubion, J. D. (ed) Power, Essential works of Foucault 1954 - 1984. London: Penguin Books, 223-238.

Foucault, M. (1994c) Governmentality. In: Faubion, J. D. (Eds) Michel Fouca ult Power Essential works of Foucault 1954 - 1984 volume 3. London: Penguin Books: 200-222.

Fraser, N. and Gordon, L. (1994) A Genealogy of Dependency: Tracinga Keyword of the U.S. Welfare State. Signs: Journal of women in Culture and Society, 19, 2, 309336.

Frayne, D. (2015) The refusal of work: The theory and practice of resistance to work London: Zed Books.

Friedli, L. and Stearn, R. (2015) Positive affect as coercive strategy: conditionality, activation and the role of psychology in UK government workfare programmes. Medical Humanities, 41, 40-47.

Goffman, E. (1990) Stigma: Notes on the Management of Spoiled Identity. London: Penguin Books.

Gov.uk (2014) A Welfare state fit for the 21st century [online]. Available at: https://www.gov.uk/government/speeches/a-welfare-state-fit-for-the-21stcentury [Accessed: 21/04/16]

Gov.uk (2015) Policy paper: 2010 to 2015 government policy: employme nt [o nline] . Available at: https://www.gov.uk/government/publications/2010-to-2015government-policy-employment/2010-to-2015-government-policy-employment [Accessed: 17/01/19]

Greer, I. (2015) Welfare reform, precarity and the re-commodification of labour. Work, Employment and Society, 1, 162-173.

Grover, C. (2003) New Labour, welfare reform and the reserve army of labour. Capital and Class, 79, 7, 17-23.

Grover, C. (2012) Personalised Conditionality Observations on active proletarianisation in late modern Britain. Capital and Class, 36, 2, 238-301.

Grover, C. and Piggott, L. (2005) Disabled people, the reserve army of labour and welfare reform. Disability \& Society, 20, 7, 705-717.

Grover, C. and Piggott, L. (2013) A commentary on resistance to the UK's Work Experience programme: Capitalism, exploitation and wage work. Critical Social Policy, 33, 3, 554-563.

Hurrell, A. (2013) Internet Access - Resolution Foundation: Starting out or getting stuck? An analysis of who gets trapped in low-paid work - and who escapes. http://www.scribd.com/doc/187541060/Starting-out-or-getting-stuck [Accessed: 02/04/19] 
p. 279. A self- governing reserve army of labour? The commodification of the young unemployed through welfare policy, practice and discourse

Ingold, J. and Stuart, M. (2015) The Demand-Side of Active Labour Market Policies: A regional Study of Employer engagement in the Work Programme. Journal of Social Policy, 44, 3, 443-462.

Jeffries, S. (2016) We took on the Tories and won! Why Liverpool's strikingschoolk ids are back. The Guardian, [online]. Available at: https://www.theguardian.com/artanddesign/2016/jul/05/wetook-on-the-toriesand-won-liverpool-striking-schoolkids [Accessed: 17/10/18]

Jensen, T. and Tyler, I. (2015) 'Benefits Broods': The cultural and political crafting of anti-welfare common sense. Critical Social Policy, 35, 4, 1-22.

Keohane, N. and Hupkau, C. (2014) Social Market Foundation report Making Progress Boosting the skills and wage prospects of the low paid. [online] Available at: http://www.smf.co.uk/wp-content/uploads/2014/06/Publication-MakingProgress-Boosting-the-skills-and-wage-prospects-of-the-low-paid.pdf [Accessed: 21/05/19]

King, D. (1995) Actively seeking work: The politics of unemployment and welfare Policy in the United States and Great Britain. Chicago: The University of Chicago Press.

Larner, W. (2000) Neo-liberalism: Policy, Ideology, Governmentality Studies. Political Economy, 63, 5-25.

Lipsky, M. (2010) Street Level Bureaucracy. US: Russell Sage Foundation.

Lowe, R. (1993) The Welfare State in Britain since 1945. Hampshire UK: Macmillan Press.

McDonald, C. and Marston, G. (2005) Workfare as welfare: governing unemployment in the advanced liberal state. Critical Social Policy, 25, 374-401.

MacDonald, R. (2011) Youth transitions, unem ployment and underemploym ent: Plus ca change, plus c'est la meme chose? Journal of Sociology, 47, 427-444.

McKenzie, L. (2015) Estates, Class and Culture in Austerity Britain. Bristol: Policy Press

Marston, G. (2013) On 'Activation Workers' perceptions': A reply to Dunn (1). Journal of Social Policy, 42, 4, 819-827.

Marx, K. (2013) \{1847 and 1865\} Wage-labour: Capital Value, price and profit. New York: International publishers.

McQuaid, R. and Lindsay, C. (2005) The concept of employability. Urban Studies, 42, 2, 197-219.

Miller, P. and Rose, N. (2011) Governing the Present. Cambridge: Polity Press.

Mizen, P. (2004) The changingstate of youth. London: Palgrave Macmillan.

ONS (2014) Office for National Statistics: Employment and Labour market [online]. Available

at: https://www.ons.gov.uk/employmentandlabourmarket/peopleinwork/earningsan dworkinghours/articles/contractswithnoguaranteedhours/2015-02-25 [Accessed: 02/02/19]

ONS (2019) Office for National Statistics: Labour market overview [online]. Available at: https://www.ons.gov.uk/employmentandlabourmarket/peopleinwork/employmen tandemployeetypes/bulletins/uklabourmarket/december2019 [Accessed: 12/12/19].

Parliament.uk (2017) Public Accounts Committee Report:Benefit Sanctions [online]. Available https://www.publications.parliament.uk/pa/cm201617/cmselect/cmpubacc/77 5/77502.htm [Accessed:12/01/19]

Patrick, R. (2012)Work as the primary 'duty' of the responsible citizen: a critique of this work-centric approach. People, Place and Policy Online, 6, 1, 5-15 [online]. Available

at: http://extra.shu.ac.uk/ppponline/issue_1_300312/documents/work_duty_respo nsible citizen critique.pdf [Accessed: 17/10/18]. 
p. 280. A self- governing reserve army of labour? The commodification of the young unemployed through welfare policy, practice and discourse

Patrick, R. (2016) Living with and responding to the 'scrounger' narrative in the UK: exploring everyday strategies of acceptance, resistance and deflection. Journal of Poverty and Social Justice, 24, 3, 245-59.

Perry, K. (2014) Take low-paid jobs in coffee bars, Employment Minister tells young people. The Telegraph, [online]. Available at: http://www.telegraph.co.uk/women/womens-politics/10588683/Take-low-paidjobs-incoffee-bars-Employment-Minister-tells-young-people.html [Accessed: 12/02/19]

Peterie, M., Ramia, G., Marston, G. and Patulny, R. (2019)Emotional Compliance and Emotion as Resistance: Shame and Anger among the Long-Term Unemployed. Work, Employment and Society, 33, 5, 794-811.

Price, D. (2000) Office of Hope: A history of the employment service. London: Policy Studies Institute.

Prior, D. and Barnes, M. (2011) Subverting social policy on the front-line: agencies of resistance in the delivery of services. Social Policy and Administration, 45, 3, 264 279.

Purnell, J. (2008) Speech to Employers Conference UKPOL Political Speech Archive [online]. Available at: http://www.ukpol.co.uk/?s=james+purnell [Accessed: 15/06/19]

Renwick, C. (2018) Bread for All: The Origins of the Welfare State. London: Penguin Books.

Roberts, K. (2013) Education to Work transitions: How the Old Middle went Missing and why the new middle remains elusive Sociological research online 18, 1, 3. Available at: http://www.socresonline.org.uk/18/1/3.html [Accessed 10/9/19]

Sage, D. (2012) Fair Conditions and Fair Consequences? Exploring New Labour, welfare contractualism and social attitudes. Social Policy and Society, 11, 3, 35973.

Sage, D. (2019) Unemployment, wellbeing and the power of the work ethic: Implications for social policy. Critical Social Policy, 39, 2, 205-228.

Shildrick, T., MacDonald, R., Webster, C. and Garthwaite, K. (2012) Poverty and Insecurity. Bristol: The Policy Press.

Slater, T. (2012)The Myth of "Broken Britain": Welfare Reform and the Production of Ignorance. Antipode, 46, 4, 948-969.

Soss, J., Fording, R.C., and Schram, F.S. (2011) Disciplining the Poor. University of Chicago Press.

Srnicek, N. and Williams, W. (2015) Inventing the Future: Post-capitalism and a World Without Work. London: Verso.

Standing, G. (2014) The Precariat: The New Dangerous Class. London: Bloomsbury.

Trickey, H. and Walker, R. (2001) Steps to Compulsion within British Labour Market Policies. In: An offeryou can't refuse (eds) Lødemel, I. and Trickey, H. Bristol: The Policy Press.

Tyler, I. (2013) Revolting Subjects Social Abjection and Resistance in Neoliberal Britain. London: Zed Books.

Umney, C. (2018) Class Matters. London: Pluto Press.

Watts, B., Fitzpatrick, S., Bramley, G. and Watkins, D. (2014) Welfare sanctions and conditionality in the UK Joseph Rowntree Foundation [online]. Available at: http://www.jif.org.uk/sites/files/irf/Welfare-conditionality-UK-Summary.pdf [Accessed: 20/05/29]

Webster, D. (2014) JSA Sanctions and Disallowances. Evidence submitted to the House of Commons Work and Pensions Committee Inquiry into the Role of Jobcentre Plus in the reformed welfare system, Second Report of Session 201314, Vol. II, pp. Ev w90-w101. Technical Report. London: House of Commons.

Weeks, K. (2011) The problem with work. Feminism, Marxism, anti-work politics and post war imaginaries. USA: Duke University Press. 
p. 281. A self- governing reserve army of labour? The commodification of the young unemployed through welfare policy, practice and discourse

Wengraf, T. (2001) Qualitative Research Interviewing. London: SAGE Publications.

Whittaker, M. and Hurrel, A. (2013) Low Pay Britain: Resolution Foundation [online]. Available at: https://www.resolutionfoundation.org/publications/low-pay-britain2013/ [Accessed: 29/01/2019].

Whitworth, A. and Carter, E. (2014) Welfare to work reform, Power and Inequality: From Governance to Governmentalities. Journal of Contemporary European Studies, $22,2,104-117$.

Wiggan, J. (2012) Telling stories of the 21st century welfare: The UK coalition government and the neoliberal discourse of worklessness and dependency. Critical Social Policy, 32, 3, 838-405.

Wiggan, J. (2015) Reading Active Labour Market Policy Politically: An autonomist analysis of Britain's Work Programmeand Mandatory Work Activity. Critical Social Policy, 35, 3, 369-392. 